\title{
What Determines Energy Production from Renewable Sources?
}

\author{
Evelina Mengova \\ Governors State University
}

Investment in renewable energy is an investment in our future. This paper analyzes the determinants of production of energy from renewable sources in Europe, the Former Soviet Union, and the Middle East and North Africa. It explores the major challenges each of these regions faces in moving towards a more environmentally friendly generation and use of energy. We find that specific country and regional characteristics, together with the energy needs and overall energy profile of a country, have a significant effect on its electricity production from renewable sources. We do not find evidence that the overall quality of governance promotes renewables.

Keywords: Renewable Energy, Energy Production, Governance.

\section{INTRODUCTION}

Investment in renewable energy sources had been an increasingly important component of national policy agendas for many countries over the past decades. One of the reasons had been the growing need for energy for both expanding industrial production, and electricity consumption. Conventional sources of energy had been limited, and fast depleting, though. That, combined with the ever-growing awareness of citizens of the negative impact of climate change, had generated also a growing need for a more diverse pool of energy sources, and notably for renewable ones.

A leader in these initiatives had been the European Union, especially in more recent years. Renewable sources would give the European Union member states a competitive, reliable and sustainable energy sector, and reduce their dependence on imports of energy. EU countries had been dependent on fossil fuel imports, especially oil and gas, which had created the need to increase the security in their energy needs.

That applied even more to Eastern European and Former Soviet Union countries, which had historically been dependent on energy imports from traditional sources, especially from the Russian Federation. During the socialist period, Russia had frequently been the only exporter of gas and oil to its satellites, often at very low prices, which created a deep reliance of these countries on Russian energy. That tradition carried over to the 1990s and generated not only a strong dependence, but also a lack of incentives to look for, and invest in, more diverse sources of energy in the whole region. Many Eastern European countries became EU members over the period 1996-2015 covered in this paper, though. As such, they joined the global initiatives of the Kyoto protocol to reduce carbon dioxide emissions, and the specific policies of the EU. EU heads of state had agreed to reduce greenhouse gases emissions $80-95 \%$ below 1990 levels by 2050 (Pacesila et al., 2016). 
In addition, according to the 2009/28/EC Directive on the promotion of using energy from renewable sources adopted by the European Parliament and of the Council of Ministers in 2009, the development of renewable energy sources became one of the main objectives of the EU Energy policy. This directive specified that the share of renewable energy in total consumption in the EU should reach the target of $20 \%$ by 2020 (European Commission, 2009). All the EU member countries were supposed to set their own national targets for 2020 regarding the share of renewable energy in different sectors of consumption, such as electricity, transportation, heating and cooling, in accordance with that Directive, and then develop national plans on how to reach those goals. Other aspects of the European countries' commitment included exchanging energy from renewable sources among members and cooperating on renewable electricity projects. Furthermore, the EU set in place a monitoring mechanism to observe the progress of each member state: since 1998 Eurobserver barometers had been registering the progress of each member state of the EU in the field of renewable energy (Pacesila et al., 2016).

On 30 November 2016, the European Commission published a proposal for a revised Renewable Energy Directive to make the EU a global leader in renewable energy, and ensure that the target of at least $27 \%$ renewables in the final energy consumption in the EU by 2030 was met (European Commission, 2016). In 2018 the European Parliament and Council provisionally agreed to revise this target upward, so that the share of energy from renewables would be at least $32 \%$ of the EU's gross final consumption in 2030 (European Parliament, 2018).

While the progress made by the EU countries towards significant policies related to renewable sources of energy implementation had been no doubt substantial, some major questions remained. Had this EU policy had enough impact on countries in Eastern Europe which had been only recently accepted in the EU? Had all these policies had enough time to be implemented in practice, so as to produce measurable results in terms of energy produced from renewable sources? Had all these policies had a spill-over effect over neighboring regions, such as the countries of the Former Soviet Union, as well as the countries in the Middle East and North Africa, which had had their specific regional challenges, but also opportunities to invest in renewable energy?

The focus of this paper was to provide an empirical evaluation over the period 1996-2015 of the determinants that affected the production of renewable energy, measured as the share of electricity produced from renewable sources. The countries covered included Europe, both Western and Eastern, as well as its neighboring countries of the Former Soviet Union, together with the Middle East and North Africa region. The paper presented convincing empirical evidence that factors related to country development, such as GDP per capita and electricity consumption per capita affected positively the share of electricity produced from renewable sources. Population growth and energy dependence, measured as energy imports, also acted as incentives to invest more in local renewables. The same could be said about the environmental profile of a country, measured by the share of carbon dioxide emissions from gas: pollution did push towards cleaner energy. The traditional sources of energy, however, such as coal, gas, nuclear and oil, were rather conservative forces, deterring investment in, and production from, cleaner sources.

We used regression analysis methodology to determine the relationship among the variables we considered. In our regressions we also controlled for other possible explanatory variables, such as energy use per capita, carbon dioxide emissions from liquid fuels consumption, together with indicators measuring the general quality of institutions and the business environment in a country. The institutional quality indicators included: control of corruption, government effectiveness, political stability, regulatory quality, rule of law, and voice and accountability. The data came from the World Bank's World Development Indicators database, which we used to analyze an unbalanced panel of 66 countries for the years 1996, 1998, 2000, and annual data for the period 2002-2015. 2015 was the last year we had available data for all the country variables included in our sample. 


\section{LITERATURE REVIEW}

Given the prominent role of the European Union in many climate change related initiatiaves, and in the creation of a rich policy framerwork to promote investment in renewable energy, an abundant share of the literature had been dedicated to EU countries and policies. Marques and Fuinhas (2011) analyzed the drivers promoting renewable energy, using a dynamic panel approach, and focusing on a set of 24 European countries for the period from 1990 to 2006. Their motivation for the choice of countries was that Europe was a leading player in the fight against climate change, and therefore its renewables market and policies deserved a deeper examination. Rio and Mir-Artigues (2014) reviewed a variety of combinations of support instruments for production of electricity from renewable sources in the EU, using different sources of data. D'Adamo and Rosa (2016) presented a research assessment of the European renewable energy sources trajectory towards achieving the 2020 targets. They also proposed a new framework to evaluate the performance of EU members, based on three indicators: the share of energy from renewable sources in gross final energy consumption, renewable energy primary production per capita, and gross final consumption of renewable energy per capita. Other studies, for example Proskurina et al. (2016), focused specifically on the role of biomass in achieving the EU's 2020 targets.

Rio et al. (2017) assessed several pathways of a harmonized European policy framework for supporting renewable electricity in a 2030 horizon according to different criteria. They discussed at length the current and future targets for renewable energy both for the EU as a whole, as well as the non-binding national targets for the member states, and the various ways to achieve them. Papież et al. (2018) explored the determinants of renewable energy development in 26 EU countries in the period 1995-2014, using a variety of statistical methods. They discovered that the distribution of energy sources in 1995 was crucial in defining the renewable energy development of a country twenty years down the road. Biesenbender and Tosun (2014) looked at environmentally friendly policy adoptions and policy changes in 24 OECD countries over a period of thirty years (1976-2005). The focus of their research were public policy innovations and their diffusion from one jurisdiction to another, exploring how environmental policies promoted by international organizations changed in different countries after their adoption. Massey et al. (2014) also analyzed climate policy innovation, by examining the adoption and diffusion of adaptation policies across 29 European countries in the period 2005-2010, to conclude it was largely driven by internal factors.

Some studies did expand the scope of research on renewables, by including also developing countries. Stadelmann and Castro (2014) looked at 112 developing and emerging countries from 1998 to 2009, focusing on the "diffusion" rather than "invention" of climate-relevant policies. They explored both domestic and international determinants of renewable energy policies adoption, to discover that countries with larger populations and more wealth exhibited a higher probability of adoption of such policies. Among the international factors, they discovered that emulation from colonial peers and EU membership seemed to facilitate renewable energy policies adoption.

Aguirre and Ibikunle (2014) investigated factors affecting country-level renewable energy growth by applying a variety of estimation methods on a global sample of 38 countries for a longer period of time: 1990-2010. They paid special attention to Brazil, Russia, India, China and South Africa to reveal new insights. Their results suggested that some government-backed energy policies in fact impeded renewable energy investments. They hypothesized that those policies could have been ineffective due to uncertainty and the likelihood of policy discontinuity. Weak voluntary approaches, following global agreements such as the Kyoto Protocol, were also found to be ineffective in promoting renewables growth, compared to mandatory measures.

Our results built on previous studies and findings. We used the EU countries as a starting point and a benchmark for renewable energy policies and practices, but then we focused also on Eastern Europe and the Former Soviet Union. We added the Middle East and North Africa to our sample of countries, because this region, less explored in the academic literature, had a generous potential to invest in renewables in the future. 


\section{EMPIRICAL ANALYSIS}

\section{Renewable Energy Production - Country Energy Profiles, Environmental and Institutional Quality Indicators}

The data set we used came from databases of the World Bank and the IMF: the World Development Indicators and the World Governance Indicators, and contained observations for 66 countries (WDI and WGI, 2019). Given the different level of economic development of the countries included in our sample, and the historical differences in the development of their institutional quality, we split the sample into four regional groups. These groups were: 1. West: Austria, Belgium, Cyprus, Denmark, Finland, France, Germany, Greece, Iceland, Ireland, Italy, Luxembourg, Netherlands, Norway, Portugal, Spain, Sweden, Switzerland, United Kingdom. 2. East: Albania, Bosnia and Herzegovina, Bulgaria, Croatia, Czech Republic, Hungary, Kosovo, Montenegro, North Macedonia, Poland, Romania, Serbia, Slovak Republic, Slovenia. 3. FSU (Former Soviet Union): Armenia, Azerbaijan, Belarus, Estonia, Georgia, Kazakhstan, Kyrgyz Republic, Latvia, Lithuania, Moldova, Russian Federation, Tajikistan, Turkmenistan, Ukraine, Uzbekistan. 4. Middle East and North Africa (MENA): Algeria, Bahrain, Egypt, Iran, Iraq, Israel, Jordan, Kuwait, Lebanon, Malta, Morocco, Oman, Qatar, Saudi Arabia, Tunisia, Turkey, United Arab Emirates, Yemen.

The indicators of institutional quality of different countries included categories such as: "Control of Corruption", "Government Effectiveness", "Political Stability and Absence of Violence/Terrorism", "Regulatory Quality", "Rule of Law", and "Voice and Accountability", measured as percentile ranks (WGI, 2019). We had an unbalanced panel for the years 1996, 1998, 2000, and annual data for the period 2002-2015.

Table 1 included some interesting comparisons of GDP per capita in these four different regions in 1996 and 2015. Even in 1996 the regional differences of income levels between the West and the other groups were substantial, and they remained substantial in 2015. Notably, the MENA region had been and remained wealthier compared to both Eastern European, and the Former Soviet Union countries, which in theory showed financial capacity to potentially invest in renewable energy production. This paper explored to what extent that financial and environmental potential was fulfilled.

TABLE 1

REGIONS BY GDP/CAPITA

\begin{tabular}{|lllll|}
\hline Year / Region & Europe: West & Europe: East & FSU & MENA \\
\hline 1996 (current USD) & $27,713.99$ & $3,834.74$ & $1,213.64$ & $8,073.90$ \\
1996 (constant 2010 USD) & $38,313.11$ & $6,917.72$ & $2,697.54$ & $13,910.03$ \\
& & & & \\
2015 (current USD) & $46,594.44$ & $9,728.48$ & $6,556.08$ & $16,827.48$ \\
2015 (constant 2010 USD) & $50,424.00$ & $11,140.55$ & $7,004.70$ & $17,424.02$ \\
\hline
\end{tabular}

Source: The World Bank, WDI (2019).

Figures 1-4 below presented the renewable electricity output (as \% of total) and the energy use (calculated as kilograms of oil equivalent per \$1,000 GDP) - measuring how efficiently countries use their energy to produce their output in those different country groups. Figure 1 indicated that Western Europe had the most efficient energy use of all the regions we explored, and that it also had the biggest production of electricity from renewable sources. It started at $131 \mathrm{~kg}$ of oil equivalent as energy use and $28 \%$ of electricity produced from renewables on average in 1996, and it accomplished an energy use indicator of $103 \mathrm{~kg}$ of oil equivalent and $44 \%$ of electricity produced from renewables on average by 2015. A lot of this success could be attributed to the concerted effort among the EU countries (and their closest allies) to have clear policies regarding the investment in, and encouragement of, energy production from renewable sources. Another reason was the wealth and stage of development of these countries, so they could generously invest in both energy efficiency, and renewable sources. They had not only the 
policies, but also the funds needed to put those policies in practice: in 2015 alone Europe invested USD 63 billion in renewable energy, with a peak new investment of USD 128 billion in 2011 (IRENA, 2019).

FIGURE 1

WESTERN EUROPE: RENEWABLE ELECTRICITY OUTPUT (\% OF TOTAL)

VS. ENERGY USE

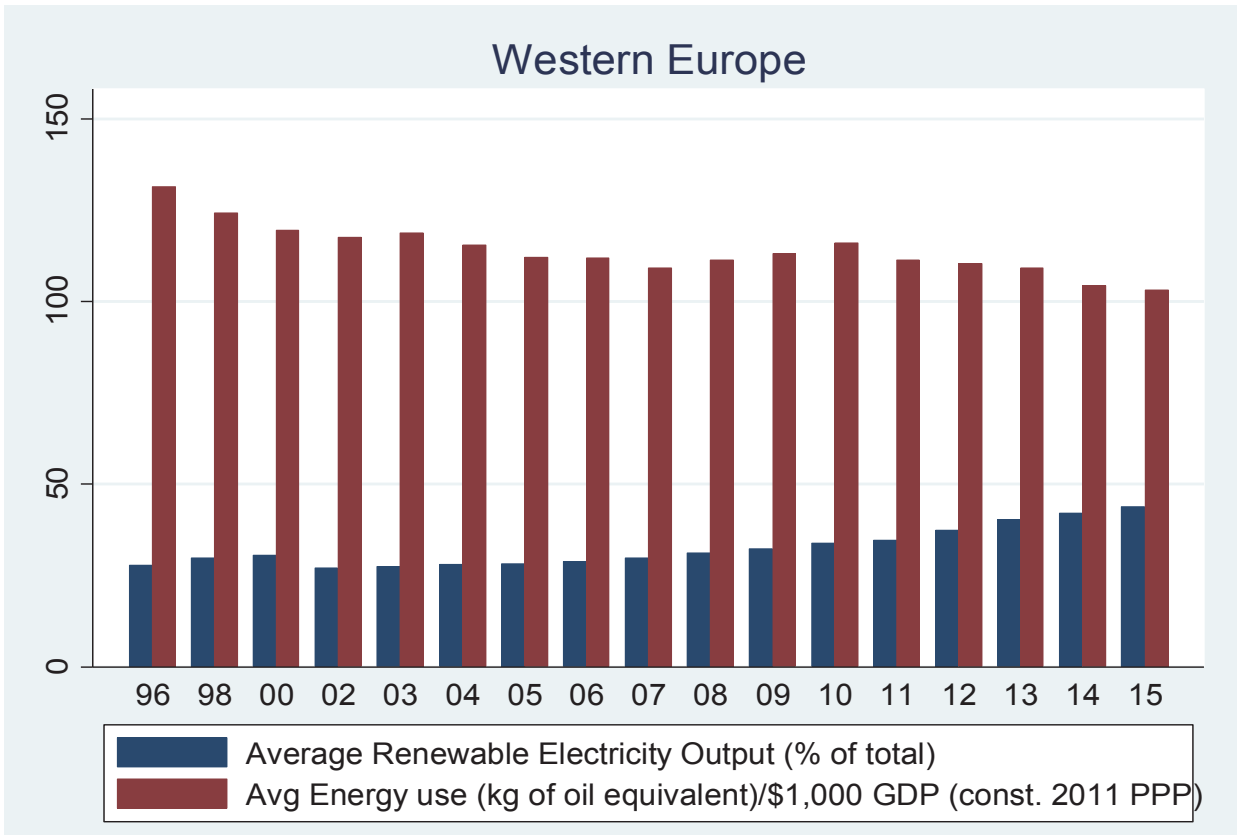

Source: WDI (2019). 


\section{FIGURE 2 \\ EASTERN EUROPE: RENEWABLE ELECTRICITY OUTPUT (\% OF TOTAL) VS. ENERGY USE}

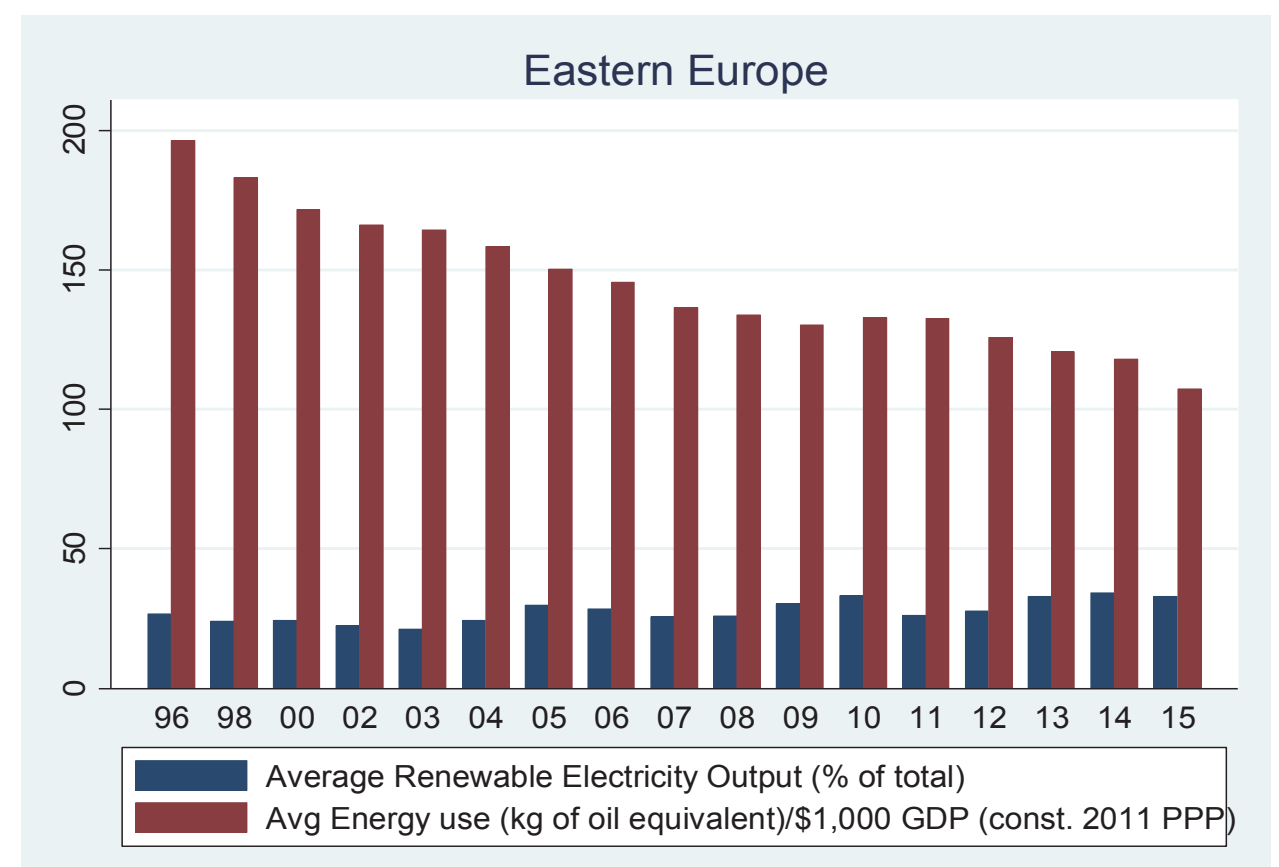

Source: WDI (2019).

Figure 2 showed that Eastern Europe had made a significant improvement in its energy use and in the production of electricity from renewable sources. It started at $196 \mathrm{~kg}$ of oil equivalent as energy use and $27 \%$ of electricity produced from renewables on average in 1996 (comparable to Western Europe at that time), to attain an energy use indicator of $107 \mathrm{~kg}$ of oil equivalent and $33 \%$ of electricity produced from renewables on average in 2015. Eastern Europe accomplished a significant improvement in its energy use overall, but also in its investment in, and production of, electricity from renewable sources. A lot of this success was likely driven by the accession of several of these countries into the EU, which provided welldefined policies and rules regarding clean energy production, as well as cohesion funds transferred to Eastern Europe, so that the region can improve its energy profile.

Figure 3 illustrated the fact that the Former Soviet Union countries started as the most energy inefficient group in 1996: using $410 \mathrm{~kg}$ of oil equivalent to produce a unit of GDP, a practice mostly driven by the access to cheap energy from Russia, to reach $151 \mathrm{~kg}$ of oil equivalent in 2015 . This was an impressive accomplishment of energy efficiency, given that this region was not particularly wealthy, and it neither had the policies, nor the investment funds provided by the EU to improve their energy profile. In terms of the share of electricity produced from renewable sources, they started at 27\% in 1996 (exactly like the rest of Eastern Europe) and got to 30\% in 2015 - also very comparable to Eastern Europe. This also indirectly indicated that the EU membership of many of the Eastern European countries did not have such a substantial impact on their investment in clean energy resources, as one might have hoped for. 
FIGURE 3

\section{FORMER SOVIET UNION: RENEWABLE ELECTRICITY OUTPUT (\% OF TOTAL)} VS. ENERGY USE

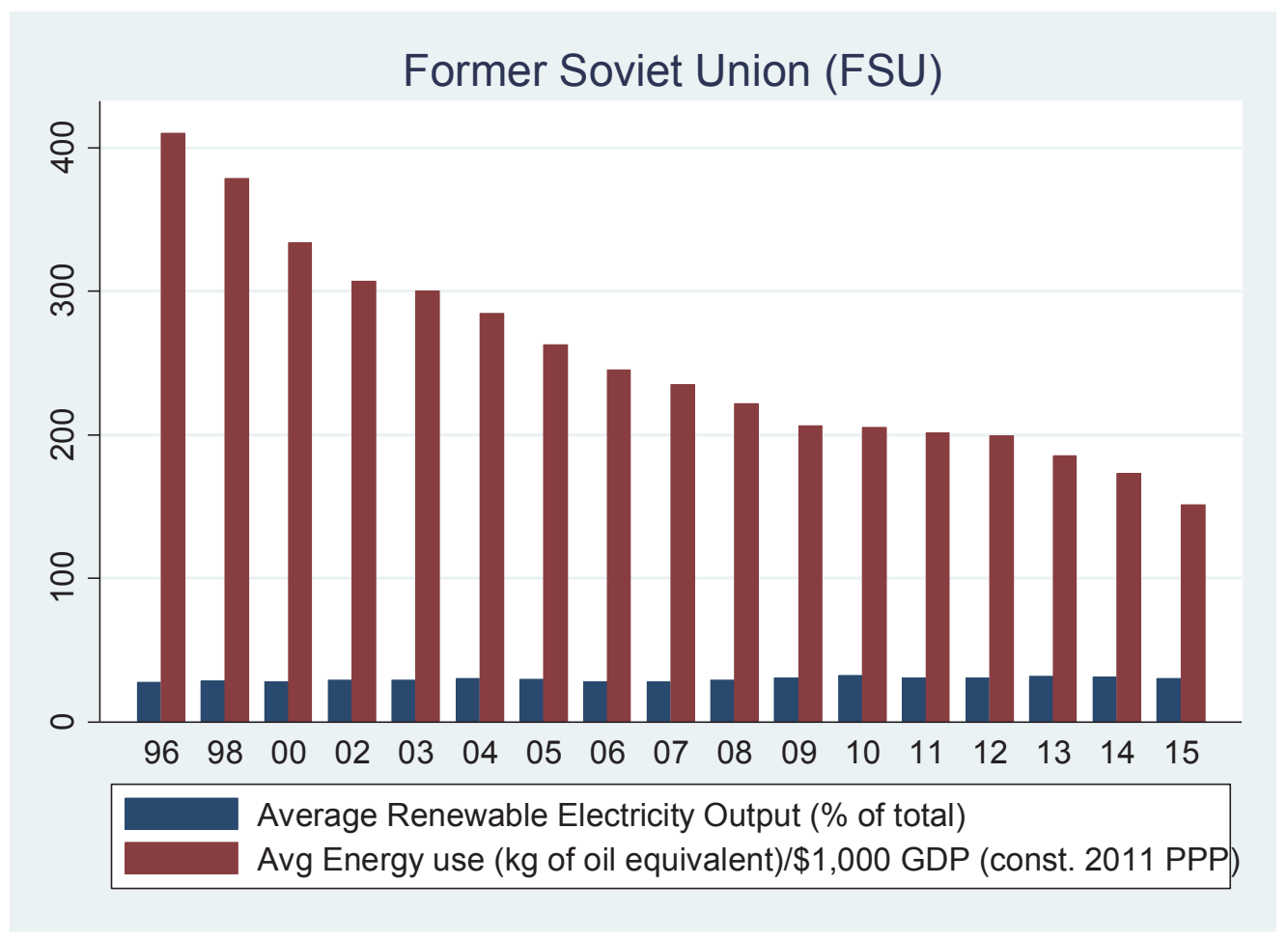

Source: WDI (2019).

The Middle East and North Africa region, quite a bit wealthier than the countries in both Eastern Europe and the FSU (as could be observed in Table 1), and therefore having the financial capability to improve its energy efficiency overall, did not register any visible change over the period 1996-2015. It started at 116 kilograms of oil equivalent per \$1,000 GDP in 1996 and saw a decrease to $79 \mathrm{~kg}$ of oil equivalent only in 2015. The share of electricity produced from renewable sources was $6 \%$ on average in 1996 and actually decreased to $4 \%$ in 2015 , despite the vast potential of the region to invest in solar and wind energy, for example. This likely illustrated the lack of incentives (or vision) to consider more seriously investing in renewable sources overall in the MENA countries during that period. However, that could change considerably in the future, according to the newest report by the International Renewable Energy Agency on the countries of the Gulf Cooperation Council (GCC) ${ }^{1}$, (IRENA, 2019). 
FIGURE 4

MIDDLE EAST AND NORTH AFRICA: RENEWABLE ELECTRICITY OUTPUT

(\% OF TOTAL) VS. ENERGY USE

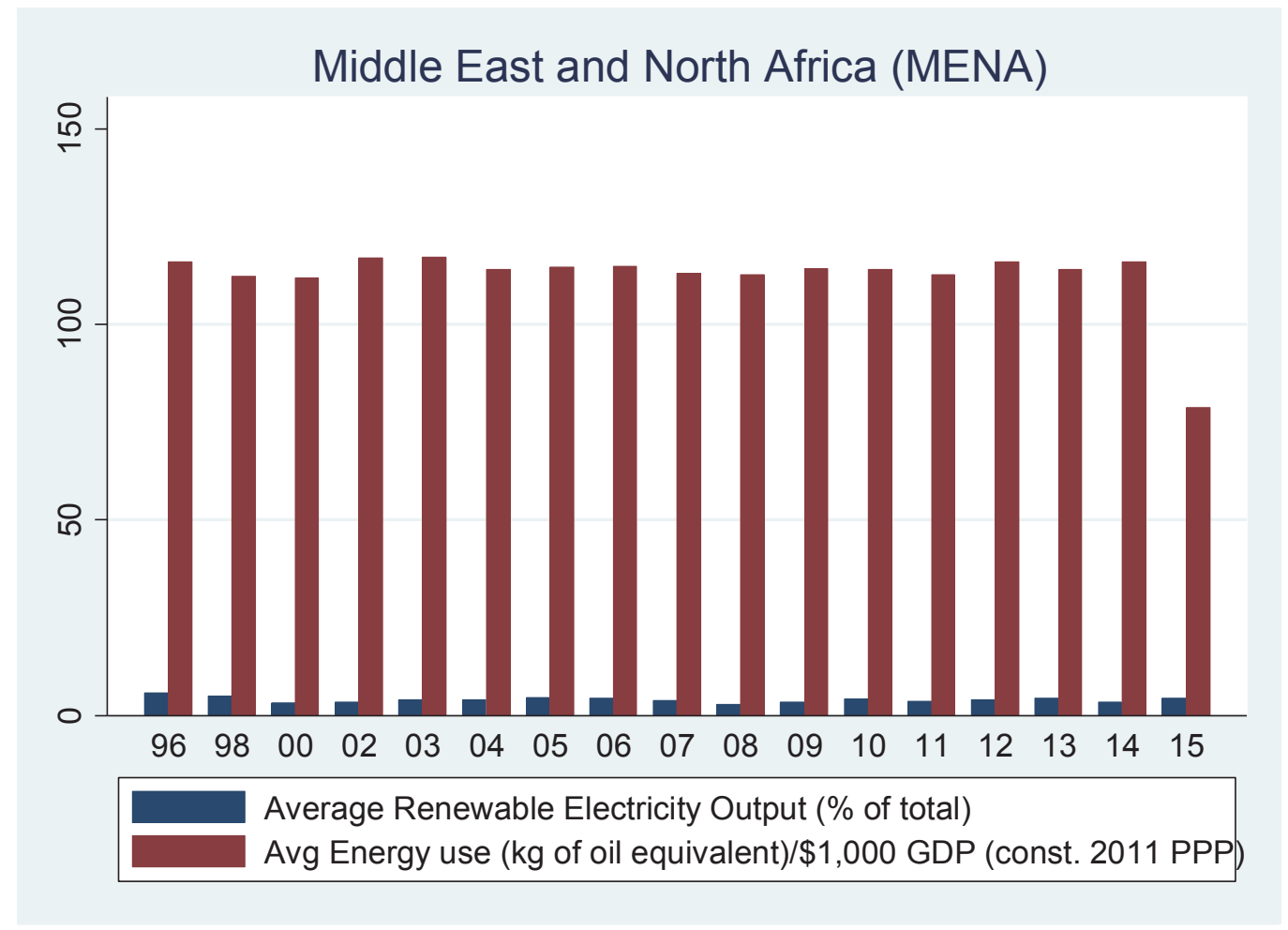

Source: WDI (2019).

\section{Models and Estimation}

The main model estimated in this paper analyzed the determinants of electricity production from renewable sources in different countries. Therefore, our dependent variable was Renewable Electricity Output $_{i j}$, i.e. the electricity output produced from renewable sources as a percentage of the total, in country $i$ and year $j$. The detailed description of all the variables used, as well as their summary statistics, were presented in Tables A1 and A2 in the Appendix. We included the following country-specific indicators:

(Renewable Electricity Output $)_{i j}=\beta_{0}+\beta_{1} *(\text { Energy Needs })_{i j}+\beta_{2} *(\text { Country Performance Indicators })_{i j}+$ $\beta_{3} *(\text { Import Dependence })_{i j}+\beta_{4} *$ (Electricity Production from Traditional Sources $)_{i j}+\beta_{5} *\left(\mathrm{CO}_{2}\right.$ Emissions from Electricity Production $)_{i j}+\beta_{6} *(\text { Institutional Indicators })_{i j}+\beta_{7} *(\text { Regional Dummies })_{i j}+\varepsilon_{i j}$,

where:

- Energy Needs reflected both the energy use per capita of a country, and the electricity consumption per capita. The energy needs of a country could be satisfied in three main ways: (1) from traditional sources, i.e. fossil-fuel based ones; (2) from renewable energy sources; (3) or from a combination of both. The hypotheses we tested here were that both higher energy use per capita, and higher electricity consumption per capita, could drive up energy production in general and create incentives for more production from renewable sources as well. In that sense, traditional sources and renewable ones could be both substitutes and complements, and therefore the expected coefficient signs were ambiguous. These variables could also be perceived as 
development indicators, meaning that higher energy needs per capita could indicate a move towards more advanced stages of a country's industrial base.

- Country Performance Indicators included GDP per capita and population growth. We expected a clear positive relationship between both higher GDP per capita, indicating a higher level of income and thus ability to invest in and promote renewable energy, and higher population growth stimulating more energy production from renewables.

- Import Dependence measured the energy security of a country. Energy dependence was considered to be a crucial policy issue for both developed EU countries, and transitional and developing countries in our sample. Theoretically the assumption was, that the higher the reliance of a country on energy imports, the higher the level of renewables investment required to ensure that country's energy security. In other words, we expected a significant positive coefficient.

- Electricity Production from Traditional Sources included all the possible alternative sources of electricity production in each country, which had been historically used even before the existence of renewable sources. Electricity generation from coal, gas, nuclear and oil sources was each included as a percentage of total electricity production and expected to have a negative impact on production from renewable sources. Part of the explanation was that they were substitutes in production. Another, more interesting part of the explanation was, that traditional sources of energy production had developed over time the ability to influence the energy sector through political and economic means. This energy mix was considered a proxy for the competition between all the conventional energy generating technologies and the renewables, as well as for the lobbying power of those traditional sources. Based on the insights gathered during our research, we anticipated that the higher the share of electricity generated from traditional sources, the less likely a country would be to pursue meaningful environmental policies. Therefore, the less proactive a country would be in the deployment of renewable sources.

- $\mathrm{CO}_{2}$ Emissions from Electricity Production accounted for $\mathrm{CO}_{2}$ emissions generated both from gaseous and from liquid fuel consumption. This was a good indicator of the environmental quality of a country, and therefore of the existing incentives to develop cleaner sources of energy. Given the huge significance of $\mathrm{CO}_{2}$ emissions in climate change, we expected that environmental concerns would have a positive impact on renewables investment.

- Institutional Indicators included control of corruption, government effectiveness, political stability, regulatory quality, rule of law, and voice and accountability. Theories of institutional quality stated that the characteristics of a political system influenced both the policy adoption, and the general business climate in a given country. The literature on the role of democracy in environmental protection was quite rich. Congleton (1992) developed a theory that authoritarian regimes would adopt less stringent environmental standards than democratic ones, since democratic governments tended to follow the preferences of the median voter, who benefited more from the public provision of environmental quality than the authoritarian ruler. That theory was also explored by Fredriksson (1997) and Deacon (2000). A study of former communist countries questioned this democracy-environment link (Midlarsky, 1998), by presenting evidence that the statistically significant effect of democracy on the environment was actually negative, contrary to previous theoretical predictions. That paper encouraged re-examining of onedimensional theoretical assumptions and policies concerning the positive effect of democracy on the environment. Other studies, such as those by Fredriksson and Gaston (2000), Neumayer (2002), and Li and Reuveny (2006), showed that stronger democracies exhibited stronger environmental commitment than weaker ones. However, Neumayer (2002) did indicate that the strong evidence in favor of a positive link between democracy and environmental commitment stood in contrast to the somewhat weak evidence on such a link between democracy and environmental outcomes themselves. Therefore, our initial theoretical hypothesis was that the more democratic the government was, the more likely it was to adopt policies that supported renewable energy deployment and to create a business environment more prone to investing in 
renewables. But we also recognized that the adoption of environmental policies by itself did not always translate into a more effective deployment of renewable sources, or into higher production of electricity from renewables.

- Regional dummy variables included dummies for Eastern Europe, the Former Soviet Union and the Middle East and North Africa, as three separate regions. The baseline was the energy performance of Western Europe, so the other three dummies captured whether a given region performed better, or worse, compared to Western Europe in terms of electricity produced from renewable sources.

\section{Estimation Results}

The results were presented in Table 2 and Table 3 below. As one could observe, most of the variables performed as expected, with some notable exceptions. The energy use per capita coefficient was significant, albeit slightly negative and small. In contrast, the electricity consumption per capita, which is a more specific measure, was positive and significant in all specifications. All of this affirmed our previous discussion that the general energy needs of a given country could be fulfilled by utilizing both traditional, and renewable, sources of energy production. Given our estimation results, it was clear that electricity consumption per capita would move to increase the electricity produced from renewable sources. As a country development indicator, this supported the hypothesis that the growing electricity needs of a developing country translated into a growing electricity production from renewables.

The GDP per capita coefficient estimate was small, but positive and significant in all specifications, suggesting that overall the more developed and the wealthier a country was, the more prone and able it was to invest in renewables, and subsequently have a higher proportion of its electricity produced from such sources. Population growth - another driver of higher energy needs, and therefore a factor promoting higher energy production from all possible souces, including renewables, was positive, and significant in most specifications.

The coeficient of energy imports, i.e. the variable accounting for energy security of a country, was positive and significant in all specifications but one. The theoretical assumption that the higher the reliance of a country on energy imports, the higher the level of renewables investment needed to ensure that country's energy security, was empirically confirmed.

All the alternative traditional sources of electricity production in each country were statistically significant and had a negative sign in each model specification. This suggested, as discovered in most of the empirical research on this topic, that those sources were substitutes to renewables in electricity production. In addition, those traditional sources likely had a well-established grid for electricity and energy delivery, together with a well-established lobby in government structures, to protect the interests of those producers and the employed labor. Theoretically, the fact that coal, gas, nuclear and oil individually all had a negative relationship with electricity production from renewables was anticipated, but it also emphasized the resilience of these industries in most countries. Traditional energy sources had habitually been preferred for economic reasons in countries that had not been constrained by environmental concerns. The traditional energy lobby had always been very influential, even in countries which had eventually become a lot more environmentally friendly. Therefore, the stronger the lobby of these traditional energy industries, the lower the likelihood that climate change related policies would be enacted, and that investment in renewable sources would be promoted.

Our hypothesis that given the huge significance of $\mathrm{CO}_{2}$ emissions in climate change, environmental concerns would have a positive impact on renewables investment was confirmed in one case: the $\mathrm{CO}_{2}$ emissions from gas proved to be statistically significant and positive in all model specifications. That suggested that in most countries higher - and more visible - pollution from gaseous fuel consumption created social, and therefore political, incentives to promote renewable sources of energy. The estimation of the $\mathrm{CO}_{2}$ emissions from liquid fuel coefficients was less convincing in this regard, producing significant but negative coefficients, albeit very small and close to zero.

All the indicators we included accounting for the general institutional quality of a country produced interesting empirical results - they were all negative and significant. Most institutional theories would 
suggest that the characteristics of a political system would influence policy adoption. In other words - the more democtratic and evolved the country was, the more likely it was to promote policies related to the abatement of industrial practices having a negative impact on climate change. Therefore the more prone a country would be to promote investment in renewable sources. However, all of these indicators reflected just policies, or perceptions of policies. But these policies might not have had a significant impact on the actual industrial practices in those countries over the period covered in our research. That was not to say that those policies would not produce positive results in the future, as most of the countries we explored become more democratic, develop better institutions, and their populations start demanding effective establishment of cleaner sources of energy over time.

The regional dummy variables also produced some very interesting results. The baseline was the renewable energy performance of Western Europe, so the other three regional dummies captured in essence how much worse did a given region perform, compared to Western Europe. Eastern Europe, for example, had negative coefficients in all specifications, but they were not statistically significant. The reason could be that although Eastern Europe had a lower starting position at the beginning of our sample in 1996, by 2015 a lot of Eastern European countries adopted a variety of policies related to environmental protection and use of cleaner energy sources. Many of those policies were adopted under the leadership of the EU and its cleaner energy requirements and commitment to investment in renewables, which could have begun to produce results in later years, and would continue to do so in the future.

The Former Soviet Union dummy, however, was high, negative and statistically significant in all specifications, suggesting that being a country in this group had a negative impact on the overall investment and promotion of renewable sources. The institutional quality variables may not have captured that, but the fact that countries with more authoritarian regimes, which generally were much less concerned with the environmental quality for their citizens, was exemplified in this regional dummy. Three of these countries: Estonia, Latvia and Lithuania, became EU members in 2004 and had experienced a compelling improvement in both their institutional and environmental quality. However, they were too small to affect the regional performance of this sub-sample.

The MENA region also showed significant and negative dummy coefficients, although not that high, in all specifications. The meaning of this result was that the countries in this region would be much less likely than Western Europe to invest in, and promote the development of renewable energy, although on average they were wealthier than both the Eastern European, and the Former Soviet Union countries, and in theory at least had the financial capability needed to invest in renewables. They also had the appropriate climate conditions to invest substantially in solar energy, yet very few of them had moved in that direction - only sporadically, and only in more recent years. The development of the renewable energy sector in the Middle East and North Africa was still a project of the future in 2015. 
TABLE 2

DEPENDENT VARIABLE: RENEWABLE ELECTRICITY OUTPUT (AS \% OF TOTAL)

\begin{tabular}{|c|c|c|c|}
\hline & $(1)$ & $(2)$ & (3) \\
\hline Energy use (per capita) & $\begin{array}{l}-0.00188^{* * *} \\
(0.000251)\end{array}$ & $\begin{array}{l}-0.00213^{* * *} \\
(0.000255)\end{array}$ & $\begin{array}{l}-0.00204^{* * *} \\
(0.000271)\end{array}$ \\
\hline Electricity consumption (per capita) & $\begin{array}{l}0.000965^{* * *} \\
(0.000111)\end{array}$ & $\begin{array}{l}0.00101^{* * *} \\
(0.000114)\end{array}$ & $\begin{array}{l}0.000944^{* * *} \\
(0.000118)\end{array}$ \\
\hline GDP per capita & $\begin{array}{l}0.000116^{* * *} \\
(0.0000310)\end{array}$ & $\begin{array}{l}0.0000940^{* *} \\
(0.0000323)\end{array}$ & $\begin{array}{l}0.0000218 \\
(0.0000315)\end{array}$ \\
\hline Population growth & $\begin{array}{l}0.430 \\
(0.242)\end{array}$ & $\begin{array}{l}0.601^{*} \\
(0.248)\end{array}$ & $\begin{array}{l}0.837^{* * * *} \\
(0.253)\end{array}$ \\
\hline Energy imports & $\begin{array}{l}0.0114^{* * *} \\
(0.00244)\end{array}$ & $\begin{array}{l}0.0115^{* * *} \\
(0.00256)\end{array}$ & $\begin{array}{l}0.00383 \\
(0.00246)\end{array}$ \\
\hline Electricity from coal ( $\%$ of total) & $\begin{array}{l}-0.817^{* * *} \\
(0.0174)\end{array}$ & $\begin{array}{l}-0.818^{* * *} \\
(0.0179)\end{array}$ & $\begin{array}{l}-0.829^{* * *} \\
(0.0183)\end{array}$ \\
\hline Electricity from gas (\% of total) & $\begin{array}{l}-0.945^{* * *} \\
(0.0193)\end{array}$ & $\begin{array}{l}-0.951^{* * *} \\
(0.0200)\end{array}$ & $\begin{array}{l}-0.916^{* * *} \\
(0.0202)\end{array}$ \\
\hline Electricity from nuclear ( $\%$ of total) & $\begin{array}{l}-0.860^{* * *} \\
(0.0203)\end{array}$ & $\begin{array}{l}-0.859^{* * *} \\
(0.0209)\end{array}$ & $\begin{array}{l}-0.865^{* * *} \\
(0.0216)\end{array}$ \\
\hline Electricity from oil ( $\%$ of total) & $\begin{array}{l}-0.849^{* * *} \\
(0.0176)\end{array}$ & $\begin{array}{l}-0.844^{* * *} \\
(0.0180)\end{array}$ & $\begin{array}{l}-0.822^{* * *} \\
(0.0185)\end{array}$ \\
\hline $\mathrm{CO}_{2}$ emissions from gas & $\begin{array}{l}0.300^{* * *} \\
(0.0276)\end{array}$ & $\begin{array}{l}0.308^{* * *} \\
(0.0284)\end{array}$ & $\begin{array}{l}0.275^{* * *} \\
(0.0291)\end{array}$ \\
\hline $\mathrm{CO}_{2}$ emissions from liquid fuel & $\begin{array}{l}-0.0000180^{* * *} \\
(0.00000443)\end{array}$ & $\begin{array}{l}-0.0000144^{* *} \\
(0.00000451)\end{array}$ & $\begin{array}{l}-0.0000167^{* * *} \\
(0.00000483)\end{array}$ \\
\hline Control of corruption (rank) & $\begin{array}{l}-0.236^{* * *} \\
(0.0205)\end{array}$ & & \\
\hline Government effectiveness (rank) & & $\begin{array}{l}-0.193^{* * *} \\
(0.0221)\end{array}$ & \\
\hline Political stability (rank) & & & $\begin{array}{l}-0.0937^{* * *} \\
(0.0188)\end{array}$ \\
\hline Eastern Europe (dummy) & $\begin{array}{l}-2.836 \\
(1.474)\end{array}$ & $\begin{array}{l}-1.574 \\
(1.500)\end{array}$ & $\begin{array}{l}0.573 \\
(1.514)\end{array}$ \\
\hline Former Soviet Union (dummy) & $\begin{array}{l}-16.95^{* * *} \\
(1.690)\end{array}$ & $\begin{array}{l}-13.84^{* * *} \\
(1.675)\end{array}$ & $\begin{array}{l}-10.71^{* * *} \\
(1.656)\end{array}$ \\
\hline Middle East \& North Africa (dummy) & $\begin{array}{l}-6.787^{* * *} \\
(1.462)\end{array}$ & $\begin{array}{l}-5.703^{* * *} \\
(1.498)\end{array}$ & $\begin{array}{l}-8.246^{* * *} \\
(1.593)\end{array}$ \\
\hline$N$ & 1022 & 1022 & 1021 \\
\hline$R^{2}$ & 0.892 & 0.886 & 0.880 \\
\hline
\end{tabular}

Standard errors in parentheses; ${ }^{*} p<0.05,{ }^{* *} p<0.01,{ }^{* * *} p<0.001$

Table 3 below presented a different set of institutional quality indicators to the main model specification: regulatory quality, rule of law, and voice and accountability. They were also based on (business people's) perceptions and used as rankings of countries. They appeared not to have a significant positive impact on electricity production from renewable sources, which meant that they did not promote or foster investment in renewables in the first place either. 
TABLE 3

DEPENDENT VARIABLE: RENEWABLE ELECTRICITY OUTPUT (AS \% OF TOTAL)

\begin{tabular}{|c|c|c|c|}
\hline & $(1)$ & $(2)$ & (3) \\
\hline \multirow[t]{2}{*}{ Energy use (per capita) } & $-0.00208^{* * *}$ & $-0.00203^{* * *}$ & $-0.00229^{* * *}$ \\
\hline & $(0.000253)$ & $(0.000251)$ & $(0.000250)$ \\
\hline \multirow[t]{2}{*}{ Electricity consumption (per capita) } & $0.000964^{* * *}$ & $0.00101^{* * *}$ & $0.00103^{* * *}$ \\
\hline & $(0.000113)$ & $(0.000112)$ & $(0.000113)$ \\
\hline \multirow[t]{2}{*}{ GDP per capita } & $0.0000987^{* *}$ & $0.000119^{* * * *}$ & $0.000132^{* * *}$ \\
\hline & $(0.0000316)$ & $(0.0000317)$ & $(0.0000327)$ \\
\hline \multirow[t]{2}{*}{ Population growth } & $0.640^{* *}$ & 0.447 & 0.176 \\
\hline & $(0.243)$ & $(0.244)$ & $(0.254)$ \\
\hline \multirow[t]{2}{*}{ Energy imports } & $0.0115^{* * *}$ & $0.0120^{* * *}$ & $0.0125^{* * *}$ \\
\hline & $(0.00251)$ & $(0.00248)$ & $(0.00252)$ \\
\hline \multirow[t]{2}{*}{ Electricity from coal ( $\%$ of total) } & $-0.815^{* * *}$ & $-0.813^{* * *}$ & $-0.815^{* * *}$ \\
\hline & $(0.0177)$ & $(0.0176)$ & $(0.0176)$ \\
\hline \multirow[t]{2}{*}{ Electricity from gas ( $\%$ of total) } & $-0.955^{* * * *}$ & $-0.945^{* * *}$ & $-0.949^{* * *}$ \\
\hline & $(0.0198)$ & $(0.0194)$ & $(0.0196)$ \\
\hline \multirow[t]{2}{*}{ Electricity from nuclear ( $\%$ of total) } & $-0.861^{* * *}$ & $-0.854^{* * *}$ & $-0.841^{* * *}$ \\
\hline & $(0.0206)$ & $(0.0205)$ & $(0.0208)$ \\
\hline \multirow[t]{2}{*}{ Electricity from oil ( $\%$ of total) } & $-0.839^{* * *}$ & $-0.839^{* * *}$ & $-0.825^{* * *}$ \\
\hline & $(0.0178)$ & $(0.0177)$ & $(0.0177)$ \\
\hline \multirow[t]{2}{*}{$\mathrm{CO}_{2}$ emissions from gas } & $0.298^{* * *}$ & $0.295^{* * *}$ & $0.254^{* * *}$ \\
\hline & $(0.0281)$ & $(0.0278)$ & $(0.0281)$ \\
\hline \multirow[t]{2}{*}{$\mathrm{CO}_{2}$ emissions from liquid fuel } & $-0.0000160^{* * *}$ & $-0.0000174^{* * *}$ & $-0.0000183^{* * *}$ \\
\hline & $(0.00000449)$ & $(0.00000446)$ & $(0.00000450)$ \\
\hline \multirow[t]{2}{*}{ Regulatory quality (rank) } & $-0.192^{* * *}$ & & \\
\hline & $(0.0196)$ & & \\
\hline \multirow[t]{2}{*}{ Rule of law (rank) } & & $-0.223^{* * *}$ & \\
\hline & & $(0.0207)$ & \\
\hline \multirow[t]{2}{*}{ Voice and accountability (rank) } & & & $-0.243^{* * *}$ \\
\hline & & & $(0.0236)$ \\
\hline \multirow[t]{2}{*}{ Eastern Europe (dummy) } & -0.571 & -2.370 & -1.827 \\
\hline & $(1.469)$ & $(1.478)$ & $(1.478)$ \\
\hline \multirow[t]{2}{*}{ Former Soviet Union (dummy) } & $-12.78^{* * *}$ & $-15.46^{* * *}$ & $-15.43^{* * *}$ \\
\hline & $(1.617)$ & $(1.665)$ & $(1.680)$ \\
\hline \multirow[t]{2}{*}{ Middle East \& North Africa (dummy) } & $-6.189^{* * *}$ & $-6.467^{* * *}$ & $-11.15^{* * *}$ \\
\hline & $(1.484)$ & $(1.471)$ & $(1.556)$ \\
\hline$N$ & 1022 & 1022 & 1022 \\
\hline$R^{2}$ & 0.888 & 0.890 & 0.889 \\
\hline
\end{tabular}

Standard errors in parentheses; ${ }^{*} p<0.05,{ }^{* *} p<0.01,{ }^{* * *} p<0.001$

\section{CONCLUSION}

Investment in renewable energy is an investment in our future. This paper explored the determinants of production of electricity from renewable sources in Europe, the Former Soviet Union and the Middle East and North Africa. It analyzed the major constraints each of these regions faced in moving towards a more environmentally friendly generation and use of energy. The paper looked for evidence whether country performance indicators (GDP per capita and population growth), environmental indicators $\left(\mathrm{CO}_{2}\right.$ emissions), together with quality of governance indicators (control of corruption, government 
effectiveness, political stability and absence of violence/terrorism, regulatory quality, rule of law, and voice and accountability) and the current energy profile of a country (energy use and electricity consumption per capita, energy imports and electricity production from traditional sources) had an impact on investment in clean energy.

We found that specific country and regional characteristics, together with the energy needs and overall energy profile of a country had a significant effect on its electricity production from renewable sources. We did not find convincing evidence that the overall quality of governance promoted energy production from renewables. Western Europe had traditionally been and remained a leader in both policy implementation and active investment and promotion of renewable sources. The Middle East and North Africa region had always had a good potential, and substantial wealth to invest in clean energy, but so far this had remained an unfulfilled potential. The countries in Eastern Europe which became EU members registered the biggest improvement in renewable policies adoption, but still needed to make a more visible progress towards renewables policy implementation and use of the EU funds. The Former Soviet Union region saw the greatest improvement in energy use efficiency, but left a lot to be desired in terms of cohesive policies and energy production from renewable sources.

\section{ACKNOWLEDGEMENTS}

The author would like to thank the participants at the MBAA International conference (2019) for helpful comments and suggestions.

\section{ENDNOTE}

1. Gulf Cooperation Council (GCC) countries include Bahrain, Kuwait, Oman, Qatar, Saudi Arabia and the United Arab Emirates.

\section{REFERENCES}

Aguirre, M., \& Ibikunle, G. (2014). Determinants of Renewable Energy Growth: A Global Sample Analysis. Energy Policy, 69, 374-384.

Biesenbender, S., \& Tosun, J. (2014). 'Domestic Politics and the Diffusion of International Policy Innovations: How Does Accommodation Happen?' Global Environmental Change, 29, 424-433.

Congleton, R.D. (1992). Political Institutions and Pollution Control. The Review of Economics and Statistics, 74, 412-421.

D'Adamo, I., \& Rosa, P. (2016). 'Current State of Renewable Energies Performances in the European Union: A New Reference Framework’ Energy Conversion and Management, 121, 84-92.

Deacon, R.T. (2000). The Political Economy of Environment-Development Relationships: A Preliminary Framework.' FEEM Nota di Lavoro. Fondazione Eni Enrico Mattei, Milano.

European Commission. (2009). Directive 2009/28/EC of the European Parliament and of the Council of 23 April 2009 on the promotion of the use of energy from renewable sources and amending and subsequently repealing Directives 2001/77/EC and 2003/30/EC.

European Commission. (2016). Revised Renewable Energy Directive. Retrieved February 18, 2019, from https://ec.europa.eu/energy/en/topics/renewable-energy/renewable-energy-directive

European Parliament. (2018). Energy: new target of 32\% from renewables by 2030 agreed by MEPs and ministers. Retrieved February 19, 2019, from http:/www.europarl.europa.eu/news/en/pressroom/20180614IPR05810/energy-new-target-of-32-from-renewables-by-2030-agreed-by-mepsand-ministers

Fredriksson, P.G. (1997). The Political Economy of Pollution Taxes in a Small Open Economy. Journal of Environmental Economics and Management, 33, 44-58.

Fredriksson, P.G., \& Gaston, N. (2000). Ratification of the 1992 Climate Change Convention: What Determines Legislative Delay? Public Choice, 104, 345-368. 
IRENA. (2019). International Renewable Energy Agency database. Retrieved March 6, 2019, from $\mathrm{http}: / /$ resourceirena.irena.or $9999 \mathrm{~g} /$ gateway/dashboard/

IRENA. (2019). Renewable Energy Market Analysis: GCC 2019. IRENA, Abu Dhabi.

Li, Q., \& Reuveny, R. (2006). Democracy and Environmental Degradation. International Studies Quarterly, 50, 935-956.

Marques, A. C., \& Fuinhas, J. A. (2011). Drivers Promoting Renewable Energy: A Dynamic Panel Approach. Renewable and Sustainable Energy Reviews, 15, 1601-1608.

Massey, E., Biesbroek, R., Huitema, D., \& Jordan, A. (2014). Climate Policy Innovation: The Adoption and Diffusion of Adaptation Policies Across Europe. Global Environmental Change, 29, 434 443.

Midlarsky, M. I. (1998). Democracy and the Environment: An Empirical Assessment. Journal of Peace Research, 35, 341-361.

Neumayer, E. (2002). Do Democracies Exhibit Stronger International Environmental Commitment? A Cross-Country Analysis. Journal of Peace Research, 39, 139-164.

Pacesila, M., Burcea, S.G., \& Colesca, S.E. (2016). Analysis of Renewable Energies in European Union. Renewable and Sustainable Energy Reviews, 56, 156-170.

Papież, M., Śmiech, S., \& Frodyma, K. (2018). Determinants of Renewable Energy Development in the EU countries. A 20-year perspective. Renewable and Sustainable Energy Reviews, 91, 918-934

Proskurina, S., Sikkema, R., Heinim, J., \& Vakkilainen, E. (2016). Five Years Left - How Are the EU Member States Contributing to the 20\% Target for EU's Renewable Energy Consumption; the Role of Woody Biomass. Biomass and Bioenergy, 95, 64-77.

Río, P. d., \& Mir-Artigues, P. (2014). Combinations of Support Instruments for Renewable Electricity in Europe: A Review. Renewable and Sustainable Energy Reviews, 40, 287-295.

Río, P. d., Resch, G., Ortner, A., Liebmann, L., Busch, S., \& Panzer, C. (2017). A Techno-Economic Analysis of EU Renewable Electricity Policy Pathways in 2030. Energy Policy, 104, 484-493.

Stadelmann, M., \& Castro, P. (2014). Climate policy innovation in the South - Domestic and International Determinants of Renewable Energy Policies in Developing and Emerging Countries. Global Environmental Change, 29, 413-423.

World Development Indicators. (2019). The World Bank Group. Retrieved from http://data.worldbank.org/indicator

World Governance Indicators. (2019). The World Bank Group. Retrieved from http://info.worldbank.org/governance/wgi/index.aspx\#home 


\section{APPENDIX}

\section{TABLE A1 \\ VARIABLES DEFINITIONS}

\begin{tabular}{|c|c|}
\hline Variable & Definition \\
\hline Renewable electricity output (\% of total) & Renewable electricity output ( $\%$ of total electricity output) \\
\hline Energy use & $\begin{array}{l}\text { Energy use (kg of oil equivalent) per } \$ 1,000 \text { GDP (constant } \\
2011 \text { PPP) }\end{array}$ \\
\hline Electricity from coal (\% of total) & Electricity production from coal sources ( $\%$ of total) \\
\hline Electricity from gas ( $\%$ of total) & Electricity production from natural gas sources ( $\%$ of total) \\
\hline Electricity from nuclear ( $\%$ of total) & Electricity production from nuclear sources ( $\%$ of total) \\
\hline Electricity from oil ( $\%$ of total) & Electricity production from oil sources ( $\%$ of total) \\
\hline Energy imports & Energy imports, net (\% of energy use) \\
\hline Electricity consumption (per capita) & Electric power consumption (kWh per capita) \\
\hline Energy use (per capita) & Energy use (kg of oil equivalent per capita) \\
\hline $\mathrm{CO}_{2}$ emissions from gas & $\mathrm{CO}_{2}$ emissions from gaseous fuel consumption ( $\%$ of total) \\
\hline $\mathrm{CO}_{2}$ emissions from liquid fuel & $\mathrm{CO}_{2}$ emissions from liquid fuel consumption $(\mathrm{kt})$ \\
\hline GDP per capita & GDP per capita (constant 2010 US\$) \\
\hline Population growth & Population growth (annual \%) \\
\hline Control of corruption (rank) & $\begin{array}{l}\text { Control of Corruption: Percentile Rank. Control of } \\
\text { Corruption captures perceptions of the extent to which public } \\
\text { power is exercised for private gain, including both petty and } \\
\text { grand forms of corruption, as well as "capture" of the state by } \\
\text { elites and private interests. Percentile rank indicates the } \\
\text { country's rank among all countries covered by the aggregate } \\
\text { indicator, with } 0 \text { corresponding to lowest rank, and } 100 \text { to } \\
\text { highest rank. Percentile ranks have been adjusted to correct } \\
\text { for changes over time in the composition of the countries } \\
\text { covered by the WGI. }\end{array}$ \\
\hline Government effectiveness (rank) & $\begin{array}{l}\text { Government Effectiveness: Percentile Rank. Government } \\
\text { Effectiveness captures perceptions of the quality of public } \\
\text { services, the quality of the civil service and the degree of its } \\
\text { independence from political pressures, the quality of policy } \\
\text { formulation and implementation, and the credibility of the } \\
\text { government's commitment to such policies. Percentile rank } \\
\text { indicates the country's rank among all countries covered by } \\
\text { the aggregate indicator, with } 0 \text { corresponding to lowest rank, } \\
\text { and } 100 \text { to highest rank. Percentile ranks have been adjusted } \\
\text { to correct for changes over time in the composition of the } \\
\text { countries covered by the WGI. }\end{array}$ \\
\hline Political stability (rank) & $\begin{array}{l}\text { Political Stability and Absence of Violence/Terrorism: } \\
\text { Percentile Rank. Political Stability and Absence of } \\
\text { Violence/Terrorism measures perceptions of the likelihood of } \\
\text { political instability and/or politically-motivated violence, } \\
\text { including terrorism. Percentile rank indicates the country's } \\
\text { rank among all countries covered by the aggregate indicator, } \\
\text { with } 0 \text { corresponding to lowest rank, and } 100 \text { to highest rank. } \\
\text { Percentile ranks have been adjusted to correct for changes } \\
\text { over time in the composition of the countries covered by the } \\
\text { WGI. }\end{array}$ \\
\hline
\end{tabular}




\begin{tabular}{|c|c|}
\hline Variable & Definition \\
\hline Regulatory quality (rank) & $\begin{array}{l}\text { Regulatory Quality: Percentile Rank. Regulatory Quality } \\
\text { captures perceptions of the ability of the government to } \\
\text { formulate and implement sound policies and regulations that } \\
\text { permit and promote private sector development. Percentile } \\
\text { rank indicates the country's rank among all countries covered } \\
\text { by the aggregate indicator, with } 0 \text { corresponding to lowest } \\
\text { rank, and } 100 \text { to highest rank. Percentile ranks have been } \\
\text { adjusted to correct for changes over time in the composition } \\
\text { of the countries covered by the WGI. }\end{array}$ \\
\hline Rule of law (rank) & $\begin{array}{l}\text { Rule of Law: Percentile Rank. Rule of Law captures } \\
\text { perceptions of the extent to which agents have confidence in } \\
\text { and abide by the rules of society, and in particular the quality } \\
\text { of contract enforcement, property rights, the police, and the } \\
\text { courts, as well as the likelihood of crime and violence. } \\
\text { Percentile rank indicates the country's rank among all } \\
\text { countries covered by the aggregate indicator, with } 0 \\
\text { corresponding to lowest rank, and } 100 \text { to highest rank. } \\
\text { Percentile ranks have been adjusted to correct for changes } \\
\text { over time in the composition of the countries covered by the } \\
\text { WGI. }\end{array}$ \\
\hline Voice and accountability (rank) & $\begin{array}{l}\text { Voice and Accountability: Percentile Rank. Voice and } \\
\text { Accountability captures perceptions of the extent to which a } \\
\text { country's citizens are able to participate in selecting their } \\
\text { government, as well as freedom of expression, freedom of } \\
\text { association, and a free media. Percentile rank indicates the } \\
\text { country's rank among all countries covered by the aggregate } \\
\text { indicator, with } 0 \text { corresponding to lowest rank, and } 100 \text { to } \\
\text { highest rank. Percentile ranks have been adjusted to correct } \\
\text { for changes over time in the composition of the countries } \\
\text { covered by the WGI. }\end{array}$ \\
\hline Middle East \& North Africa (MENA) & MENA=1 if country belongs to MENA region; 0 otherwise \\
\hline & WEST $=1$ if country belongs to WEST region; 0 otherwise \\
\hline Eastern Europe (EAST) & EAST $=1$ if country belongs to EAST region; 0 otherwise \\
\hline Former Soviet Union (FSU) & FSU $=1$ if country belongs to FSU region; 0 otherwise \\
\hline
\end{tabular}

Source: The World Bank, World Development Indicators and World Governance Indicators (2019). 
TABLE A2

DESCRIPTIVE STATISTICS

\begin{tabular}{|llllll|}
\hline Variable & N & Mean & Std. Dev. & Min & Max \\
\hline Renewable electricity output (\% of total) & 1122 & 23.11983 & 28.66635 & 0 & 100 \\
Energy use & 1070 & 153.2244 & 105.5745 & 46.36578 & 876.5415 \\
Electricity from coal (\% of total) & 1114 & 19.46067 & 26.06675 & 0 & 98.14909 \\
Electricity from gas (\% of total) & 1114 & 31.63726 & 33.99115 & 0 & 100 \\
Electricity from nuclear (\% of total) & 1074 & 10.61389 & 19.46407 & 0 & 85.84447 \\
Electricity from oil (\% of total) & 1114 & 12.65174 & 25.64242 & 0 & 100 \\
Energy imports & 1072 & -21.16422 & 164.0121 & -843.4819 & 100 \\
Electricity consumption (per capita) & 1048 & 5978.929 & 6453.756 & 120.1426 & 54799.18 \\
Energy use (per capita) & 1072 & 3483.781 & 3252.786 & 219.5899 & 21959.44 \\
CO $_{2}$ emissions from gas & 1027 & 28.43618 & 22.61798 & 0 & 132.205 \\
CO emissions from liquid fuel & 1027 & 49012.39 & 78311.21 & -16967.21 & 424924.6 \\
GDP per capita & 1183 & 21533.33 & 22502.62 & 365.4377 & 111968.4 \\
Population growth & 1187 & 1.021824 & 2.020647 & -5.924734 & 16.33164 \\
Control of corruption (rank) & 1185 & 58.22595 & 29.4232 & .5376344 & 100 \\
Government effectiveness (rank) & 1175 & 62.01102 & 27.09872 & .5102041 & 100 \\
Political stability (rank) & 1172 & 54.06116 & 28.8344 & 0 & 100 \\
Regulatory quality (rank) & 1174 & 62.71807 & 27.55683 & .5128205 & 100 \\
Rule of law (rank) & 1185 & 59.31703 & 29.23804 & .4784689 & 100 \\
Voice and accountability (rank) & 1187 & 54.8112 & 32.17015 & 0 & 100 \\
Middle East \& North Africa (MENA) & 1188 & .2727273 & .4455493 & 0 & 1 \\
Western Europe (WEST) & 1188 & .2878788 & .452965 & 0 & 1 \\
Eastern Europe (EAST) & 1188 & .2121212 & .4089824 & 0 & 1 \\
Former Soviet Union (FSU) & 1188 & .2272727 & .4192467 & 0 & 1 \\
\hline Sourc: Tre Wor & & &
\end{tabular}

Source: The World Bank, World Development Indicators and World Governance Indicators (2019). 